\title{
Generol Ent?onology \\ Sources of resistance to black aphid in cowpea varieties used as green grains
}

\author{
Vinicius Borges ${ }^{1 \varpi \bullet}$, Daniel Rodrigues Nere ${ }^{2 \oplus}$, Leandro Carvalho da Silvat ${ }^{\oplus}$, \\ Marília Gomes Caminha ${ }^{2}$, Ervino Bleicher ${ }^{2}$ \& Cândida Hermínia Campos de Magalhães Bertini
}

1. Universidade de São Paulo - Escola Superior de Agricultura Luiz de Queiroz. 2. Universidade Federal do Ceará. † In memorian

\section{EntomoBrasilis 13: e902 (2020)}

\section{Edited by:}

Rodrigo Souza Santos

Article History:

Received: 12. iii.2020

Accepted: 16.vi.2020

Published: 21.vii.2020

$\bowtie$ Corresponding author:

Vinicius Borges

乃 viniborrj@hotmail.com

Funding agencies:

$\triangle$ WMEC-SESU, especially the Tutorial Education Program (PET); Conselho Nacional de Desenvolvimento Científico e Tecnológico (CNPq)

\begin{abstract}
Evaluation of resistance of Vigna unguiculata L. landraces, used as green beans, to Aphis craccivora Koch was tested. Eleven landraces and standard genotypes were used in a free choice protocol: BR 17-Gurguéia, VITA 7 (susceptible), BRS Guariba and TVu 408P2 (resistant). A completely randomized blocks design was used with six replicates. Seedlings were infested with five six-day-old adult insects. The number of alive adults after $48 \mathrm{~h}$ and of alive nymphs after $96 \mathrm{~h}$ was evaluated. The results evidenced that there are high genetic diversity among the landraces, the antibiosis as the main mechanism of resistance. By means of multivariate analysis we suggest crosses among the commercial cultivar BRS Guariba and the most dissimilar varieties CCE-088, CCE-075, CCE-013 and CCE-062 to obtain superior hybrids.
\end{abstract}

Keywords: Aphididae, Black Aphid, Cowpea bean, Genetics, Mosaic Virus.

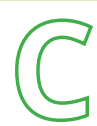
owpea bean [Vigna unguiculata (L.) Walp., Fabaceae] is planted mainly in the tropical and subtropical regions of the world, being grown mainly for obtaining dry grains, however their versatility allows it to be used as a vegetable, using leaves, pods and green grains (ALABI et al. 2012; ONUSIHI et al. 2013). However, several factors contribute to low productivity (500 kg/ha) of this crop, and among them, arthropod pests such as the black aphid [Aphis craccivora Koch (Hemiptera: Aphididae)] is considered a key pest for the crop, causing direct damage and transmitting viruses as: Cowpea Severe Mosaic Virus (CPSMV), Cowpea Aphid-Borne Mosaic Virus (CABMV) and Cucumber Mosaic Virus (CMV) (TANZUBIL et al. 2008; OliveIRA et al. 2012).

The control of this pest is done basically with chemical insecticides that can cause toxicological and environmental problems (Silva \& Bleicher 2010). Another strategy to control $A$. craccivora could be the use of resistant varieties of $V$. unguiculata (MORAES \& BlEICHES 2007). The search for genes for resistance to this pest started at the International Institute of Tropical Agriculture (IITA) with SINGH (1977). Similar prospections were made later by Moraes \& Bleicher (2007), Rodrigues et al. (2010), Silva \& Bleicher (2010), Silva et al. (2012), Bandeira et al. (2015) and Melville et al. (2016), in Brazil. However, no specific research has been carried out on genotypes already used by local producers, with the aim of selecting resistant genes to $A$. craccivora for later use in breeding programs.

The aim of this research was to verify the resistance to the black aphid in cowpea varieties intended for consumption as green grains, using univariate and multivariate analyzes.

\section{MATERIAL AND METHODS}

The research was conducted from July to August 2015, in the municipality of Fortaleza, Ceará state, Brazil, on the premises of the Department of Phytotechnics of Universidade Federal do Ceará (UFC), located at Campus do Pici, on a screen covered laterally with anti-aphid screen (Zanata $\left.{ }^{\circledR}\right)$ and covered with plastic $200 \mu$ thick, being positioned at the coordinates of $3^{\circ} 44^{\prime} 48^{\prime \prime} \mathrm{S}$ and $38^{\circ} 34^{\prime} 30^{\prime \prime} \mathrm{W}$, at $12 \mathrm{~m}$ above sea level.

The experimental design used was completely randomized blocks. The experimental unit was composed of a plant in a pot, using six replications. The plants for each block were defined by their size and volume. Each experimental unit was identified with a $15 \mathrm{~cm}$ wooden marker, with graphite annotation. Polyethylene pots of $300 \mathrm{~mL}$ capacity were used with three holes in the base, and a substrate composed of soil, earthworm humus and vermiculite in the proportion of 6:3:1 (SiLVA \& BLEICHER 2010).

The treatments were composed of local varieties, two resistant genotypes ("BRS Guariba" and TVu $408 \mathrm{P}_{2}$ ) and two susceptible genotypes (BR-17 Gurguéia and VITA 7) to A. craccivora (Singh 1977; Moraes \& Bleicher 2007; Silva \& BLEICHER 2010), totaling 15 sample materials (Table 1). The seeds were provided by provided by active germoplasm bank of Universidade Federal do Ceará and by the genetic breeding program of Embrapa Meio Norte. Three days after emergence, extra seedlings were removed, leaving only one 
plant per pot. Manual Irrigation was performed daily until infestation. After the infestation, two daily irrigations were made, to keep the soil always in the field capacity and prevent escape of the insects from the plants.

The infestation of the plants was made 20 days after planting, transferring five adult females of black aphid with a moistened brush (Moraes \& Bleicher 2007). The individuals were obtained from the maintenance colony of the department (Adults previously identified using diagnosis provided by PeÑA-Martínez 1992). These adults were in the beginning of reproduction stage, with six days old. After $24 \mathrm{~h}$, adults were removed, remaining only the nymphs produced in this period.

Each block of plants was placed immediately after infestation on a table, without touching each other and covered with a $1.0 \times 1.0 \times 0.5 \mathrm{~m}$ cage, covered with anti-aphid screen. The evaluation was made in two stages. In the first, $48 \mathrm{~h}$ after the infestation, the living adult insects (NLA) were counted and removed. Living insects were those that showed a reaction when touched. In the second stage, the number of living nymphs (NLN) was assessed $96 \mathrm{~h}$ after infestation (MORAEs \& BLEICHER 2007).

For univariate analysis the data of live adults and nymphs were transformed by the formula $(x+0.5)^{0.5}$, and the means separated by the Scott-Knott test at the level of $5 \%$ probability. The averages of NLA and NLN were also ranked according to the methodology proposed by MULAMBA \& Mock (1978), assigning ranks to the averages, with the lowest rank being the average with the highest priority for improvement (more resistant). The sum of the two rankings is called effective resistance (ER), which is the potential of resistance of the genotype in question against $A$. craccivora. This effective resistance was also ranked by the same criteria already described.

The data referring to the NLA, NLN and ER rankings were subjected to a normality and homogeneity test of the variance of the errors and then, without transformation, a new analysis was performed, with the averages separated by Scott-Knott at the $p<0.05$, with results presented in the form of averages of occupied positions (XP).
The variables, NLA and NLN were also submitted to the multivariate statistical test of Cluster Analysis (AA) using the generalized Mahalanobis distance by the unweighted connection method (UPGMA) to form a dendrogram. The co-phenetic correlation coefficient (CCC) was also calculated to verify the fit between the dissimilarity matrix and the dendrogram. The multivariate analysis was performed using the Genes statistical program (CRUz 2006).

\section{RESULTS AND DISCUSSION}

Differences were found for the variables NLA and NLN, indicating the existence of genetic variability (Table 2). Regarding the number of adults (NLA), it was found that the analysis separated the varieties into three groups: highly resistant, moderately resistant and susceptible (Table 2). It can also be observed that the average number of adults varied from zero to five, for the resistant genotype (BRS Guariba) and susceptible genotype (VITA 7), respectively.

Reproductive performance (Table 2), expressed by the number of live nymphs, is the main parameter used to assess the antibiosis exerted by a genotype (OBOPILE \& OSITILE 2010). In this study, the statistical analysis showed the formation of three distinct groups for the number of nymphs, identical to those reported for adults.

Several factors can influence the insect's fertility, and consequently, its reproductive potential in a host. Among these is the possible presence of secondary metabolites, with antibiotic characteristics, as well as the nutritional quality of the plant (PANIZZI \& PARRA 2009). In this case, it can be assumed that the average of nymphs on the CCE-064 genotype could be directly influenced by one or both of the factors mentioned.

The analysis using the positions occupied by the genotypes, regarding the variables number of adults, number of nymphs and the effective resistance, has his result expressed by the average of the stations (XP), pointing to the formation of seven statistically distinct groups (Table 2 ). This result indicates the great genetic variability between the varieties evaluated. This variability, related to the resistance to the black aphid, may be useful to the genetic improvement programs of this culture in order to prevent the possible

Table 1. Access code, genotypes and place of origin or collection of string beans used by producers in the form of green beans.

\begin{tabular}{|c|c|c|}
\hline Code & Genotype & Origin \\
\hline CCE-064 ${ }^{\prime \prime}$ & Cowpea bean & Lajedo, Ceará State (Brazil). \\
\hline$C E-25 \stackrel{2 \prime}{\prime}$ & Cowpea bean & Active Germoplasm Bank of UFC \\
\hline CCE-108 & Cowpea bean & Tururu, Ceará State (Brazil). \\
\hline CCE-092 & Cowpea bean & Paraíba State (Brazil) \\
\hline CCE-082 & Cowpea bean & Apuiarés, Ceará State (Brazil). \\
\hline CCE-010 & Cowpea bean & Deputado Irapuan Pinheiro, Ceará State (Brazil). \\
\hline CCE-062 & Cowpea bean & Farias Brito, Ceará State (Brazil). \\
\hline CCE-044 & Cowpea bean & Apodi, Rio Grande do Norte State (Brazil) \\
\hline CCE-013 & Cowpea bean & Guaraciaba do Norte, Ceará State (Brazil). \\
\hline CCE-075 & Cowpea bean & Farias Brito, Ceará State (Brazil). \\
\hline CCE-088 & Cowpea bean & Apuiarés, Ceará State (Brazil). \\
\hline BR 17-Gurguéia & Suceptible & Embrapa Meio Norte \\
\hline BRS Guariba & Resistant & Embrapa Meio Norte \\
\hline VITA 7 & Suceptible & International Institute of Tropical Agriculture - IITA - Nigéria \\
\hline TVu $408 \mathrm{P}_{2}$ & Resistant & International Institute of Tropical Agriculture - IITA - Nigéria \\
\hline
\end{tabular}

$1 /$ access code from the work collection of genotypes from Department of Phytotechnics of Universidade Federal do Ceará; $2 /$ access code from Active Germoplasm Bank from Universidade Federal do Ceará. 
Table 2. Number of living adults (NLA), number of living nymphs (NLN), effective resistance (ER), rank occupied in ranking ( $p$ ) and average ranks (XP) of different genotypes of cowpea (Vigna unguiculata) used for consumption in the form of green grain relative to resistance to Aphis craccivora.

\begin{tabular}{|c|c|c|c|c|c|c|c|c|c|}
\hline Genotype & NAV & & $\boldsymbol{p}^{(1)}$ & NNV & & $p^{(1)}$ & RE & $p^{(1)}$ & $X^{(2)}$ \\
\hline BRS Guariba & $0.0^{(3)}$ & $c^{(4)}$ & 1 & $0.8^{(3)}$ & $c^{(4)}$ & 1 & 2 & 1 & $1.0 a^{14}$ \\
\hline CCE-064 & 0.2 & c & 2 & 10 & c & 2 & 4 & 2 & $2.0 \mathrm{a}$ \\
\hline CE-25 & 1.3 & $\mathrm{~b}$ & 3 & 42.3 & $b$ & 3 & 6 & 3 & $3.0 \mathrm{~b}$ \\
\hline TVu $408 \mathrm{P}_{2}$ & 1.3 & $\mathrm{~b}$ & 3 & 47.8 & $b$ & 4 & 7 & 4 & $3.7 \mathrm{~b}$ \\
\hline CCE-108 & 2.3 & $b$ & 4 & 63.2 & $b$ & 5 & 9 & 5 & $4.7 \mathrm{c}$ \\
\hline CCE-092 & 3.3 & a & 5 & 79.8 & a & 6 & 11 & 6 & $5.7 \mathrm{c}$ \\
\hline CCE-082 & 3.7 & $\mathrm{a}$ & 6 & 94.7 & $a$ & 7 & 13 & 7 & $6.7 \mathrm{c}$ \\
\hline CCE-010 & 4.0 & $a$ & 7 & 102 & a & 8 & 15 & 8 & $7.7 \mathrm{~d}$ \\
\hline CCE-062 & 4.2 & $a$ & 8 & 108 & a & 10 & 18 & 9 & $9.0 \mathrm{e}$ \\
\hline CCE-044 & 4.7 & a & 10 & 105 & a & 9 & 19 & 10 & $9.7 \mathrm{e}$ \\
\hline CCE-013 & 4.2 & $a$ & 8 & 109 & a & 11 & 19 & 10 & $9.7 \mathrm{e}$ \\
\hline BR 17-Gurguéia & 4.5 & $a$ & 9 & 116 & a & 12 & 21 & 11 & $10.7 \mathrm{f}$ \\
\hline CCE-075 & 4.5 & $a$ & 9 & 118 & a & 13 & 22 & 12 & $11.3 \mathrm{f}$ \\
\hline VITA 7 & 5.0 & $a$ & 11 & 119 & a & 14 & 25 & 13 & $12.7 \mathrm{~g}$ \\
\hline CCE-088 & 4.7 & $a$ & 10 & 125 & a & 15 & 25 & 13 & $12.7 \mathrm{~g}$ \\
\hline C.V. $\%^{(5)}$ & \multicolumn{2}{|c|}{39.43} & & \multicolumn{2}{|c|}{45.14} & & & & 13.00 \\
\hline
\end{tabular}

(1) Rank occupied by ranking according with Mulamba \& Mock (1978); (2) Rank averages; (3) Number of adults and nymphs transformed by ( $x+0,5)^{0,5}$. (4) Averages followed by same letter, in same column do not differ statistically by Scott-Knott test at 5\% of probability. (5) Coefficient of variation.

effects of a narrowing of the genetic base.

The result of the multivariate analysis, generated by the UPGMA method, is represented by the dendrogram contained in Figure 1. By assigning a cut-off point of 50\%, two similarity groups are obtained. The first group was formed by varieties with similar resistance patterns to A. craccivora (BRS Guariba, TVu 408P2, CCE-064, CCE-108 and CE-25. A second group was formed by genotypes that were susceptible to black aphid (VITA 7, BR 17-Gurguéia and the other varieties). VIANA et al. (2009) use a second cutoff point, which in this article was arbitrated at 20\% (1.47). In this case, subgroups are obtained within the initial groups, which are closer to the results obtained in the univariate analysis (Table 2 ).

In order to obtain a new cultivar in a shorter period of time, a backcrossing between BRS Guariba, which is a commercially used cultivar, with local varieties CCE-064, CCE-108 and CE25 , could make a combination of characteristics already approved by producers and resistance to A. craccivora. On the other hand, if the option is to obtain superior hybrids, it is suggested the crossing of more dissimilar genotypes, like BRS Guariba with the varieties CCE-088, CCE-075, CCE013 and CCE -062, as these can be useful in expanding the genetic base.
The value of the co-phenetic correlation coefficient (CCC) was equal to 0.8741 , with an adequate adjustment between the dissimilarity matrix and the dendrogram, since as reported by ROHLF (1970), values greater than 0.7 indicate the adequacy of the method grouping.

The advantage of using these genotypes is that they exert less selective pressure on aphids, delaying the appearance of resistant biotypes that can cause some of the available genetic material to lose, as Souleymane et al. (2013) and Aliyu \& ISHIYAKu (2013). According to these same authors, it is still unclear how an insect with telithytic parthenogeny, such as $A$. craccivora, suddenly produces biotypes. However, rare mutations, chromosomal rearrangement and mitotic recombination may be involved in the appearance of these biotypes (Aliyu \& ISHIYAKU 2013). In a review by Moraes \& BLEICHER (2007), five biotypes of the black aphid were reported in Nigeria. These facts show the relevance of the continuous search for genotypes with resistance to this insect in local varieties.

The studied genotypes showed high genetic variability related to the resistance parameter to the aphid $A$. craccivora. The antibiosis was the main resistance mechanism of the genotypes; and it is suggested to backcross BRS Guariba with CCE-064, CCE-108 and CE-25 to incorporate the agronomic

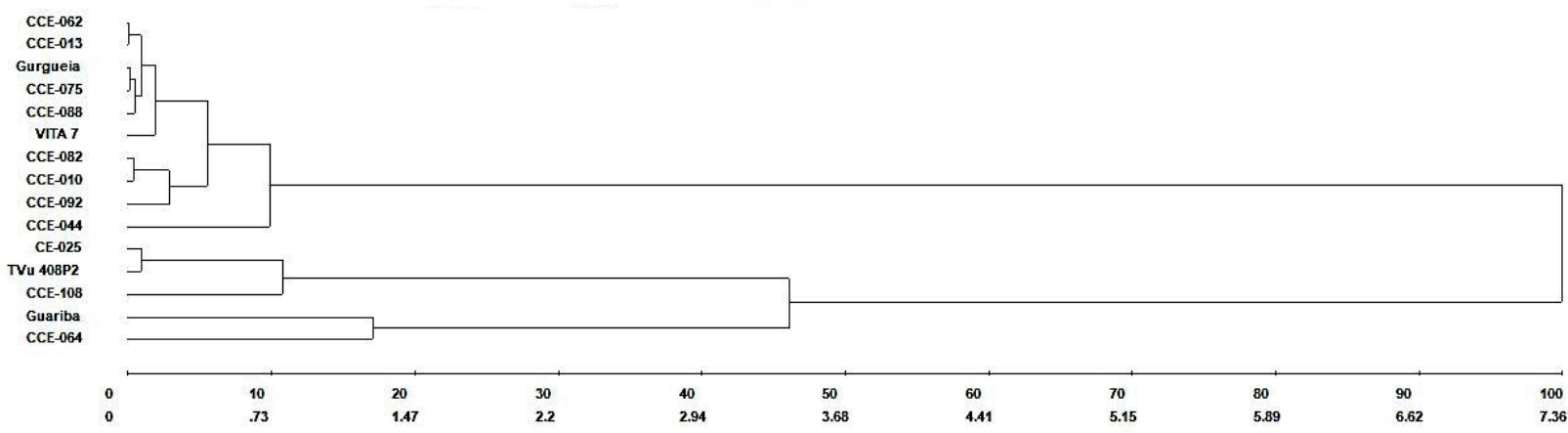

Figure 1. Reduced Dendrogram of Cluster Analysis from the number of live adults (NLA) and number of live nymphs (NLN) of black aphids in different genotypes of cowpeas, used for consumption in the form of green grain, a generalized Mahalanobis distance is used. 
characteristics of the commercial cultivar to local varieties in a short period of time.

\section{ACKNOWLEDGEMENT}

To MEC-SESu, especially the Tutorial Education Program (PET), to the Conselho Nacional de Desenvolvimento Científico e Tecnológico (CNPq) for the financial assistance and granting of scholarships. To the Instituto Federal de Educação, Ciência e Tecnologia do Ceará (IFCE) for the release to take a PhD course.

\section{REFERENCES}

Alabi, OY, E Aziza \& AA Omoloye, 2012. Preliminary evaluation of selected cowpea varieties for resistance to cowpea aphid, Aphis craccivora. Nigerian Journal of Ecology, 12: 4555

Aliyu, H \& MF Ishiyaku, 2013. Identification of novel resistance gene sources to cowpea aphid (Aphis craccivora Koch) in cowpea (Vigna unguiculata L.). Pakistan Journal of Biological Sciences, 16: 743-746. DOI: https://doi.org/10.3923/ pjbs.2013.743.746

Bandeira, HFS, ACS Lima, A Strucker, LB Trassato \& LFS Dionisio, 2015. Preferência do pulgão-preto e da cigarrinha-verde em diferentes genótipos de feijão-caupi em Roraima. Revista Agro@mbiente On-line, 9: 79-85. DOI: https://doi.org/10.5327/Z1982-8470201500011998

Melville, CC, ACS Lima, EG Morais \& NT Oliveira, 2016. Preferencia do pulgão-preto, Aphis craccivora Koch (Hemiptera: Aphididae), a genótipos de feijão-caupi. Resista Agro@mbiente On-Line, 10: 153-160. DOI: https://doi.org/10.18227/1982-8470ragro.v10i2.3042

Moraes, JGL \& E Bleicher, 2007. Preferência do pulgãopreto, Aphis craccivora Koch, a diferentes genótipos de feijão-de-corda, Vigna unguiculata (L.) Walp. Ciência Rural, 37: 1554-1557. DOI: https://doi.org/10.1590/S010384782007000600008

Mulamba, NN \& J Mock, 1978. Improvement of yield potential of the method Eto Blanco maize (Zea mays L.) population by breeding for plant traits. Egyptian Journal of Genetics and Cytology, 7: 40-51.

Oliveira, CRR, FR, Freire Filho, MSR Nogueira, GB Barros, M Eiras, VQ Ribeiro \& CA Lopes, 2012. Reação de genótipos de feijão-caupi revela resistência às infecções pelo Cucumber mosaic virus, Cowpea aphid-borne mosaic virus e Cowpea severe mosaic vírus. Bragantia, 71: 59-66. DOI: https://doi.org/10.1590/S0006-87052012005000007

Obopile, M \& B Ositile, 2010. Life table and population parameters of cowpea aphid, Aphis craccivora Koch
(Homoptera: Aphididae) on five cowpea Vigna unguiculata (L. Walp.) varieties. Journal Pest Science, 83: 9-14. DOI: https://doi.org/10.1007/s10340-009-0262-0

Onusihi, GC, JC Harriman, AA Ngwuta, EO Okporie \& SC Chukwu, 2013. Efficacy of some cowpea genotypes against major insect pest in southeastern agro-ecology of Nigeria. Meddle-East Journal of Scientific Research, 15: 114-121. DOI: https://doi.org/10.5829/idosi.mejsr.2013.15.1.2277

Panizzi, AR \& JRP Parra, 2009. Bioecologia e nutrição de insetos - base para o manejo integrado de pragas. Brasília, Embrapa.

Peña-Martinez, R, 1992. Identificação de afídeos, pp. 136-143. In: Urias, MC, MR Rodriguez, AT Alejandre (Eds). Identificación de afidos de importância agricola. Montecillo, Centro de Fitopatologia, v.2.

Rohlf, FJ, 1970. Adaptive Hierarchical Clustering Schemes. Systematic Biology, 19: 58-82.

Rodrigues, SR, O Oliveira-Junior, G Ceccon, AM Correa \& AR Abot, 2010. Preferência de Aphis craccivora por genótipos de feijão-caupi de porte prostrado, em Aquidauana, MS. Revista Ceres, 57: 751-756. DOI: https://doi.org/10.1590/ S0034-737X2010000600008

Silva, JF \& E Bleicher, 2010. Resistência de genótipos de feijão-de-corda ao pulgão-preto. Pesquisa Agropecuária Brasileira, 45: 1089-1094. DOI: https://doi.org/10.1590/ S0100-204X2010001000006

Silva, JF, CHM Bertini, E Bleicher \& JGL Moraes, 2012. Divergência genética de genótipos de feijãode-corda quanto à resistência ao pulgão-preto. Pesquisa Agropecuária Brasileira, 47: 948-954. DOI: https://doi.org/10.1590/S0100-204X2012000700011

Singh, SR, 1977. Cowpea cultivars resistant to insect pests in world germplasm collection. Tropical Grain Legume Bulletin, 9: 3-7.

Souleymane, A, ME Aken'ova, CA Fatokun \& OY Alabi, 2013. Screening for resistance to cowpea aphid (Aphis craccivora Koch) in wild cultivated cowpea (Vigna unguiculata) Walp. Accessions. International Journal of Science, Environment and Technology, 2: 611-621.

Tanzubil, PB, M Zakariah \& A Alem, 2008. Integrating host plant resistance and chemical control in the management of cowpea pests. Australian Journal of Crop Science, 3: 115-120.

Viana, CLTP, AS Bortoli, RT Thuler, RM Goulart, AMG Thuler, MVF Lemos \& AS Ferraudo, 2009. Efeito de novos isolados de Bacillus thuringiensis Berliner em Plutella xylostella (Linnaeus, 1758) (Lepidoptera: Plutellidae). Biologia, 37: 22-31.

$\star \star * \star * \star * \star * *$

\section{Suggestion citation:}

Borges, V, DR Nere, L C da Silva, MG Caminha, E Bleicher \& CHCM Bertini, 2020. Sources of resistance to black aphid in cowpea varieties used as green grains. EntomoBrasilis, 13: e902.

Available in: doi: 10.12741/ebrasilis.v13.e902

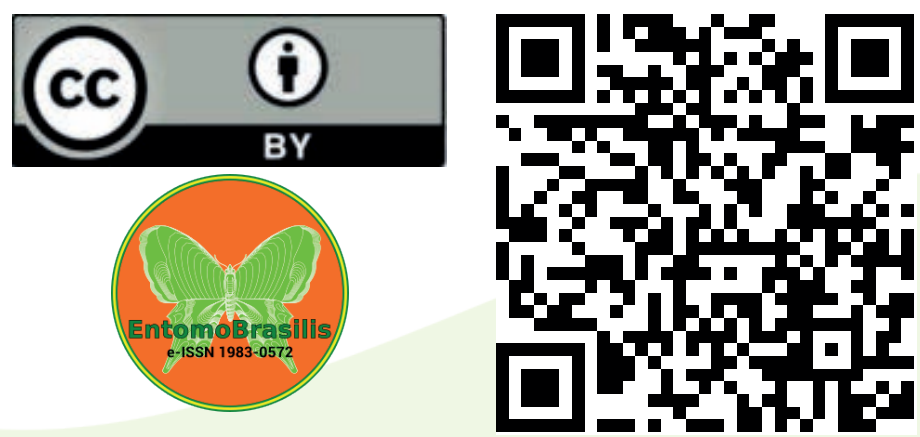

